\title{
Vitamin A deficiency in Brazilian Children younger than 5 years old: a systematic review
}

Dixis Figueroa Pedraza 1

(iD) https://orcid.org/0000-0002-5394-828X

${ }^{1}$ Universidade Estadual da Paraíba. Av. das Baraúnas, 351. Campina Grande, PB, Brasil. CEP: 58.429-500. E-mail: dixisfigueroa@hotmail.com

\begin{abstract}
Objectives: to examine the nutritional status of vitamin A in Brazilian children under 5 years old, delimiting their deficiency and associated factors.

Methods: this is a systematic review of articles published between 2008 and 2018, using the SCiELO, Bireme, and PubMed electronic databases. A validated instrument critically evaluated the studies. The summary measures were obtained by the random effect model, and their results are presented using the Forest Plot graph. The qualitative synthesis was based on the description of the main factors associated with Vitamin A Deficiency.

Results: we included 14 cross-sectional studies with observations in basic health units, daycare centers, and households. The summary measure indicated Vitamin A Deficiency of $20 \%(C 195 \%=17 \%-23 \%)$, with high homogeneity according to the source of the sample. Lower age of the child, low birth weight, poor iron nutritional status, diarrhea, subclinical infection, inadequate basic sanitation conditions, younger mothers and less maternal education represented the main exposures associated with the outcome.

Conclusion: the results show Vitamin A Deficiency as a public health problem in Brazilian children under 5 years old, especially when related to the development of infectious processes and maternal and child characteristics that show greater susceptibility.
\end{abstract}

Key words Vitamin A, Vitamin A deficiency, Child 


\section{Introduction}

Vitamin A is an essential nutrient for a normal vision, maintaining the immune functions, growth, and development. The lack of this micronutrient can cause Vitamin A Deficiency (VAD), which is one of the main causes of preventable blindness in childhood and is related to the increase and severity of infections. ${ }^{1-5}$ Due to the increased nutritional demands and the severity of the possible consequences for health associated with VAD, preschoolers and pregnant women are the most vulnerable segments to the disease. 1-3 Therefore, the fight against VAD is essential to the child's survival, well-being, and adequate growth and development.

The World Health Organization (WHO) estimates that approximately $33.3 \%$ of children under 5 years old (190 million) have VAD (serum retinol $<0.70 \mu \mathrm{mol} / \mathrm{L}$ ). ${ }^{1}$ Analyzes conducted with 82 countries that implement supplementation programs for Vitamin A showed that in 34 of them, VADis a serious public health problem, while in eight of them is moderate. ${ }^{4}$ In Latin America, 19 countries have interventions to combat the disease, and in 16 of them, VAD is a public health problem. Eight of these countries have classificatory proportions of severe or moderate intensity, according to a systematic review of the literature published between 1985 and 2014.6 In 2006, a shortage of $17.4 \%$ of children under 5 years old was identified in Brazil, 7 the average prevalence estimated in a review study with children assisted in daycare centers was $12.5 \% .8$

Despite the availability of such information, the existence of outdated data from diagnoses occurred mainly before 2006,4,9 including in Brazil.7 In Brazil, the lack of evaluation studies of the National Program of Vitamin A Supplementation impairs knowledge about its effectiveness. 10 The Program aims to prevent and control VAD, focusing on children aged 6 to 59 months. ${ }^{11}$

Thus, given the importance of the vitamin A nutritional status for child health and the updated statistics on VAD for the surveillance and implementation of public policies related to the problem in question, it was considered relevant to examine the nutritional status of vitamin A in Brazilian children under the age of five years old, delimiting their disability and associated factors.

\section{Methods}

The study is a systematic review of scientific articles on VAD in Brazilian children under 5 years old, complied with the PRISMA recommendation for reporting systematic reviews and meta-analyses.

\section{Eligibility criteria}

We considered eligible observational studies on VAD developed with Brazilian children under 5 years old, published between 2008 and 2018. The choice of the year 2008 considered the characteristics of the last review of the wide-ranging theme, released that year, and included published articles between 1994 and 2007.12 We considered records in English, Spanish and Portuguese analyzing the original articles with populations from Brazil that included children under five years old in their analysis.

\section{Information sources}

We identified the studies in SciELO (Scientific Electronic Library Online), Bireme (Virtual Health Library), and PubMed (National Library of Medicine) databases. The search was conducted on August 11, 2019.

\section{Search strategy}

All documents containing the combination of the descriptors "Child" OR "Pre-school" AND "Vitamin A deficiency" were considered. At SciELO, records before 2008 were deleted manually. At Bireme, the search considered Brazil with the filters of "country/region" as a subject the years of 2008 to 2018 as "year of publication". In PubMed, the descriptor "Brazil" was included and the personalized date range between 2008/01/01 and 2018/12/31 was used as a filter. The search was conducted in English and Portuguese. The complete electronic search strategy reproduced in English was as follows: i. Child [All indexes] or Child, Preschool [All indices] and Vitamin A Deficiency [All indexes], in SciELO; ii. (tw: (child)) OR (tw: (Child, Preschool)) AND (tw: (Vitamin A Deficiency)) and filters Brazil, in the country/region as a subject, and 201020142015201620132012200820092011 2017, in publication year, at Bireme; iii. (((child) OR Child, Preschool) AND Vitamin A Deficiency) AND Brazil and filter from 2008/01/01 to 2018/12/31, on publication dates, on PubMed.

\section{Selection of studies}

When calculating the total number of studies, we identified possible duplications in the databases in which we counted each record only once. The identi- 
fied records were submitted to a screening process and, upon reading the titles and abstracts, we eliminated (i) the documents other than scientific articles, (ii) review articles, (iii) program evaluation studies, (iv) studies of experimental design, (v) studies on food consumption, (vi) studies focusing on chemical analysis of food, (vii) studies not carried out with samples of children under 5 years old, (viii) studies on individuals diagnosed with some disease. After the screening process, we submitted the chosen papers to the inclusion and exclusion criteria, with a thorough reading and analysis of the full text. For inclusion in this review, we considered studies that addressed hypovitaminosis A in children under 5 years old. We excluded studies (i) with a non-representative sample/no description of the sample calculation, (ii) with children submitted to specific supplementation, (iii) without VAD indicators for the age group of interest, (iv) addressing different themes. Also, for articles that used the same study sample, we included only one of them and in the quality assessment phase, the exclusion criterion adopted was to obtain a low-quality indicative score The lists of bibliographic references of the included articles were analyzed to identify other possible studies of interest. The articles selected from the bibliographic references were submitted to the samepreviously described eligibility criteria.

\section{Data collection process}

To ensure the accuracy and reliability of results from the review, the articles identified in databases that met the selection criteria were grouped in folders. Two researchers (DFP and ESS) independently performed data collection during the screening, full reading, and extraction phases. For data extraction, a form was created with information on the methodological aspects and main findings of the studies. Another researcher participated in the discussion of doubts and/or disagreements.

The variables extracted from the articles for their characterization were: author, year of publication, objective, place of study, an age considered, sample size, investigation of subclinical infection, tests of hypotheses used, the prevalence of VAD (serum retinol $<0.70 \mu \mathrm{mol} / \mathrm{L})^{1}$ and variables associated with VAD. Also, we verified the biochemical indicator and the analysis techniques usedin all studies. The importance of considering the control or not of the subclinical infection by the researchers is because infectious processes can suppress the mobilization of vitamin A as a result of the low synthesis of the retinol transport protein during the acute phase, resulting in the fall of the concentration in plasma retinol. ${ }^{13}$ The articles were also evaluated for their quality.

\section{Quality evaluation of included articles}

We evaluated the quality of studies using the critical evaluation instrument for prevalence studies developed and tested by Munn et al. 14 This instrument has ten questions about the adequacy and accuracy of the study, related to validity of the methods, interpretation and applicability results. Thus, each article was checked against the representativeness of target population through the sample, recruitment of participants, sample size, description of the subjects and study scenario, data analysis, possibility of bias, reliability of the information on the outcome, ownership of statistical methods, identification of confounding factors and differences between groups, and use of objective criteria to identify subpopulations or subgroups. Each item was evaluated with one point when the answer was positive or "does not apply", half a point when the answer was uncertain, and zero points when the answer was negative, generating a maximum score of 10 points. The score of each article classified them in three quality categories: high ( 8 to 10 points), medium (5 to 7 points), and low (0 to 4 points).

\section{Summary of the results}

To obtain summary measures, we used a metaanalysis with a random effect model, generating the forest plot graph. The heterogeneity between studies was analyzed using $\mathrm{I}^{2}$ statistics. The analyzes were performed using the STATA 12.0 program. The number of times that a given factor was associated with VAD was also quantified, considering relevant those that appeared in more than one article. Both the average prevalence weighted by the sample size and the qualitative synthesis of the factors associated with VAD were generated for the set of studies included in the review and for subgroups according to their distribution in agreement with the source of the sample (basic health unit, daycare center, and household survey).

\section{Results}

Figure 1 shows the flowchart of the process of identification and selection of studies. After reading in full, 13 articles were eligible, in which, by reverse search, we identified two others that met the inclusion criteria. Only one article was excluded 
according to the quality evaluation, totaling 14 articles eligible for review.

Table 1 shows the general characterization of the studies and their quality evaluation. We included 14 articles with cross-sectional designs. ${ }^{15-28}$ One of the studies was focused on in the whole country, ${ }^{16} 10$ were focused on cities in the Northeast, $15,17,19,21,22,24-28$ one was in a city in the North region 23 and the other two were in the capitals of Goiás 18 and Espírito Santo. ${ }^{20}$ Nine observations were based on household data, 15,16,22-28 while the other studies had samples obtained from daycare centers $17,19,21$ and basic health units. ${ }^{18,20}$ Most articles reported analyzes of inflammatory processes that interfere with serum retinol levels.15,1719,21,23,25,26 Latex agglutination,21,25,26 chemiluminiscence 18,23 and immunoturbidimetric assay 15,19 were the most used methods for measuring C-reactive protein, while the values $>5 \mathrm{mg} / \mathrm{dL} 15,18,23$ and $>6 \mathrm{mg} / \mathrm{dL} 19,21,25$ were the main cutoff points used as the indicatives of the presence of subclinical infection. Most studies were classified as high quality, ${ }^{15-}$

\section{Figure 1}

Fluxograma das fases de identificação, triagem e seleção de artigos publicados entre 2008 e 2018 sobre deficiência de vitamina A em crianças brasileiras menores de cinco anos.

Estudos identificados nas bases de dados eletrônicas (vocábulos utilizados na busca: "crianças" OR "pré-escolar" AND "deficiência de vitamina A", com os filtros Brasil para local e 2008 a 2018 para período) ( $n=127:$ SciELO=9, Bireme=64, PubMed=54)

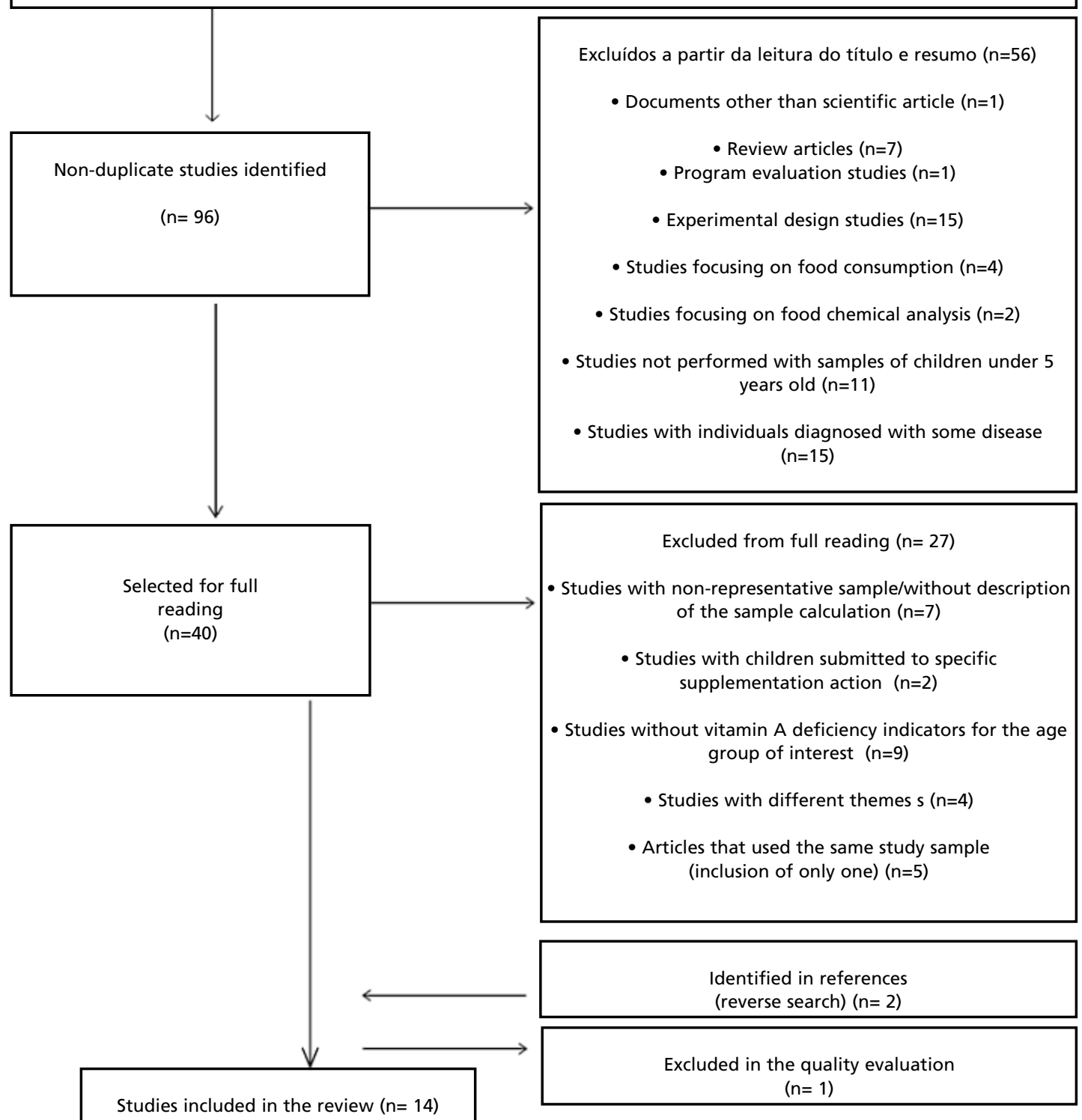


17,19,21-27 with the sample selection process being the item with the highest number of negative evaluations. $15,18,20,28$

As for the biochemical indicator and analysis techniques (data not shown in the table), serum retinol was used as a marker of the vitamin A nutritional status and values $<0.70 \mu \mathrm{mol} / \mathrm{L}$ to define its inadequacy in all studies. ${ }^{1}$ All researchers used highperformance liquid chromatography to measure serum retinol concentrations, except in one of the studies that opted for spectrophotometry. ${ }^{20}$ The venous blood sample was reported in all studies in which this information was available, 15,18-23,25-28 while only four articles reported whether the collection had happened or not, in the child's fasting, ${ }^{17-}$ 19,25 a condition that was considered in two of the cases. 17,18

Table 2 shows the synthesis of the main results of studies. VAD varied from $9.3 \% 15$ to $45.4 \% .26$ Statistical associations were not reported in two articles. 21,23 The presence of subclinical infection was identified as an associated factor to VAD in two 15,25 of the four articles 15,18,23,25 in which there were analyzes with values adjusted for the concentration of C-reactive protein.

Figure 2 shows the result of the summary of the effect of meta-analysis, which was 0.20 $(\mathrm{CI} 95 \%=0.17-0.23)$. According to the origin of the sample, the values were similar, from 0.21 $(\mathrm{CI} 95 \%=0.18-0.24)$ in basic health units, 0.20 $(\mathrm{CI} 95 \%=0.12-0.28)$ in daycare centers and 0.20 $(\mathrm{CI} 95 \%=0.16-0.24)$ in household surveys. The heterogeneity $\left(\mathrm{I}^{2}\right)$ of $94.53 \%(p=0.00)$ is considered high.

Analyzes of the factors associated with VAD highlight that younger children, ${ }^{17,26}$ who were born with low weight, 24,26 with iron-deficient nutritiona status, $18-20,27$ with episodes of diarrhea in the last 15 days, 22,24 with subclinical infection, $15,22,25$ living in households with inadequate basic sanitation conditions, $22,25,28$ of younger mothers 17,24 and in cases of lower maternal education 18,26 represented the main explanatory conditions for the occurrence of the lack of VAD. Of these factors, the nutritional status of iron deficiency was common, in the subgroup of studies developed in basic health units, 18,20 and low birth weight, 24,26 the presence of subclinical infection, $15,22,25$ and the inadequate conditions of basic sanitation, 22,25,28 in the subgroup of studies carried out as household surveys. Table 3 shows the synthesis of these results.

\section{Discussion}

This work synthesizes cross-sectional studies with Brazilian children under 5 years old that addressed the biochemical diagnosis of the nutritional status of vitamin A. We included articles based on studies that used representative random samples, guaranteeing the applicability of the results obtained. In all studies, the diagnosis of prevalence of VAD used as a cutoff point the analyzed serum retinol values of $<0.70 \mu \mathrm{mol} / \mathrm{L},{ }^{1}$ using the high-performance liquid chromatography method, except for one study that guarantees methodological similarities in aspects of the systematization process. The control of the negative effect of subclinical infection in the serum retinol biomarker reported in eight articles guarantees in these studies an accurate evaluation of the nutritional status of vitamin A, while in the other studies, the possibility of over estimated prevalence should be considered in case of corrections have not been made and inflammatory processes are present in the observed children. ${ }^{29}$ Despite this, the results show the existence of isolated experiences related to the biochemical evaluation of the nutritional status of vitamin A, similar to findings in aprevious review, specific for children assisted in daycare centers. This explains this situation based on the difficulties of blood collection in children, the high costs and the technical problems of the analyzes. 8

The average prevalence weighted by the sample size of VAD estimated for the set of children in the studies in this review was $20 \%(\mathrm{CI} 95 \%=17 \%$ $23 \%$ ) and it is within the WHO epidemiological classification as a public health problem of severe degree $(\geq 20 \%) .{ }^{1}$ This proportion is higher than in children assisted in daycare centers ${ }^{8}$ and that diagnosed in Brazilian children. ${ }^{7}$ According to a review that used population-based data, considering populations of children from developing countries, the prevalence found in this study is only lower than that of regions where the problem is also a serious public health one (Sub-Saharan Africa: 48\%; 25 - 75 and South Asia: 44\%; 13 - 79) and higher than estimated for Latin America and the Caribbean (11\%; 4 - 23). ${ }^{9}$

The high prevalence found is inserted in a reality that can be considered positive considering the priority given to the reduction and control of VAD in Brazilian children from 6 to 59 months old through the National Vitamin A Supplementation Program. ${ }^{11}$

However, evaluative results on the Program point out deficiencies that include a fragmented work process, irregularity in supplementation, lack of standardization, and failure to carry out food and 
Table 1

\begin{tabular}{|c|c|c|c|c|c|c|c|}
\hline Author, Year & Objective & Place of study & $\begin{array}{c}\text { Age } \\
\text { (months old) }\end{array}$ & Sample & $\begin{array}{l}\text { Investigation of subclinical } \\
\text { infection }\end{array}$ & $\begin{array}{c}\text { Hypothesis testing } \\
\text { used }\end{array}$ & $\begin{array}{l}\text { Study } \\
\text { quality }\end{array}$ \\
\hline Teles et al.15 2018 & $\begin{array}{l}\text { To evaluate the relation- } \\
\text { ship between serum } \\
\text { retinol concentrations } \\
\text { and subclinical infection } \\
\text { in children from rural } \\
\text { settlements }\end{array}$ & $\begin{array}{l}\text { Teresina (PI) (house- } \\
\text { hold survey in rural } \\
\text { settlements) }\end{array}$ & $6-59$ & 118 & $\begin{array}{l}\text { Reactive protein } C \text { measured by an } \\
\text { immunoturbidimetric assay, defining va- } \\
\text { lues }>5 \mathrm{mg} / \mathrm{L} \text { as the indicative of the } \\
\text { presence of infection (analyzes with val- } \\
\text { ues adjusted for protein concentration) }\end{array}$ & $\begin{array}{l}\text { Pearson's Correlation } \\
\text { Coefficient } \\
\text { T-student } \\
\text { ANOVA } \\
\text { Multiple Linear } \\
\text { Regression }\end{array}$ & High \\
\hline Lima et al.,16 2018 & $\begin{array}{l}\text { To analyze variables asso- } \\
\text { ciated with VAD in } \\
\text { Brazilian children aged } 6 \\
\text { to } 59 \text { months old }\end{array}$ & $\begin{array}{l}\text { Brazil (household po- } \\
\text { pulation survey) }\end{array}$ & $6-59$ & 3.417 & Not considered & Poisson Regression & High \\
\hline $\begin{array}{l}\text { Novaes et al..,17 } \\
2016\end{array}$ & $\begin{array}{l}\text { To determine the preva- } \\
\text { lence of VAD and associ- } \\
\text { ated factors in children } \\
\text { attending daycare centers }\end{array}$ & $\begin{array}{l}\text { Vitória da Conquista } \\
\text { (BA) (full-time public } \\
\text { daycare centers) }\end{array}$ & $24-60$ & 259 & $\begin{array}{l}\text { Reactive Protein C measured by ne- } \\
\text { phelometry, defining values }>10 \mathrm{mg} / \mathrm{dL} \\
\text { as the indicative of the presence of } \\
\text { infection (analyzes excluding the cases of } \\
\text { altered protein) }\end{array}$ & $\begin{array}{l}\text { Chi-square } \\
\text { Fisher's exact test } \\
\text { Logistic Regression }\end{array}$ & High \\
\hline Silva et al.,18 2015 & $\begin{array}{l}\text { To evaluate the nutrition- } \\
\text { al status of vitamin } A \text { and } \\
\text { associated factors in chil- } \\
\text { dren treated at basic } \\
\text { health units }\end{array}$ & $\begin{array}{l}\text { Goiânia (GO) (basic } \\
\text { health units) }\end{array}$ & $12-16$ & 228 & $\begin{array}{l}\text { Reactive protein } C \text { measured by chemilu- } \\
\text { minescence, defining values }>5 \mathrm{mg} / \mathrm{L} \text { as } \\
\text { the indicative of the presence of infec- } \\
\text { tion (analyzes with values adjusted by } \\
\text { the concentration of CRP) }\end{array}$ & $\begin{array}{l}\text { Chi-square } \\
\text { Multiple Linear } \\
\text { Regression }\end{array}$ & Average \\
\hline $\begin{array}{l}\text { Figueroa Pedraza et } \\
\text { al.,192014 }\end{array}$ & $\begin{array}{l}\text { To estimate the isolated } \\
\text { and combined prevalence } \\
\text { of anemia, VAD and zinc } \\
\text { deficiency in preschool } \\
\text { children }\end{array}$ & $\begin{array}{l}\text { Daycare centers of the } \\
\text { State Secretariat for } \\
\text { Human Development } \\
\text { of the Government of } \\
\text { Paraíba (public day- } \\
\text { care centers) }\end{array}$ & $12-72$ & 240 & $\begin{array}{l}\text { Reactive protein } C \text { measured by immuno- } \\
\text { turbidimetric assay, defining values } \\
>6 \mathrm{mg} / \mathrm{L} \text { as the indicative of the presence } \\
\text { of infection (analyzes excluding the cases } \\
\text { of altered protein) }\end{array}$ & $\begin{array}{c}\text { T-student } \\
\text { Chi-square } \\
\text { Gross and adjusted } \\
\text { Odds Ratio calculation }\end{array}$ & High \\
\hline
\end{tabular}




\begin{tabular}{|c|c|c|c|c|c|c|c|}
\hline Author, Year & Objective & Place of study & $\begin{array}{c}\text { Age } \\
\text { (months old) }\end{array}$ & Sample & $\begin{array}{l}\text { Investigation of subclinical } \\
\text { infection }\end{array}$ & $\begin{array}{c}\text { Hypothesis testing } \\
\text { used }\end{array}$ & $\begin{array}{c}\text { Study } \\
\text { quality }\end{array}$ \\
\hline Saraiva et al.20 2014 & $\begin{array}{l}\text { To analyze the occurrence } \\
\text { of anemia and iron defi- } \\
\text { ciency in children aged } 1 \\
\text { to } 5 \text { years old and the } \\
\text { association of these out- } \\
\text { comes with retinol defi- } \\
\text { ciency }\end{array}$ & $\begin{array}{l}\text { Vitória (ES) (basic } \\
\text { health units) }\end{array}$ & $12-60$ & 692 & Not considered & $\begin{array}{c}\text { Spearman's } \\
\text { Correlation } \\
\text { Coefficient } \\
\text { Poisson regression } \\
\text { with robust adjust- } \\
\text { ment of variance }\end{array}$ & Average \\
\hline $\begin{array}{c}\text { Pedraza et al.,21 } \\
2014\end{array}$ & $\begin{array}{l}\text { To analyze the associa- } \\
\text { tion between food (in) } \\
\text { security and the nutri- } \\
\text { tional status of children } \\
\text { assisted in daycare cen- } \\
\text { ters }\end{array}$ & $\begin{array}{l}\text { Cities with public day- } \\
\text { care centers of the } \\
\text { government of Paraiba } \\
\text { (public daycare cen- } \\
\text { ters) }\end{array}$ & $<60$ & 193 & $\begin{array}{c}\text { Reactive Protein C measured by Latex } \\
\text { Agglutination, defining values }>6 \mathrm{mg} / \mathrm{L} \\
\text { as the indicative of the presence of } \\
\text { infection (analyzes excluding the cases of } \\
\text { altered protein) }\end{array}$ & $\begin{array}{l}\text { T student } \\
\text { Chi-square } \\
\text { Multiple Linear } \\
\text { Regression }\end{array}$ & High \\
\hline $\begin{array}{l}\text { Silva de Paula et } \\
\text { al.,22 } 2014\end{array}$ & $\begin{array}{l}\text { To describe the preva- } \\
\text { lence and factors associa- } \\
\text { ted with anemia and VAD } \\
\text { in children under } 5 \text { years } \\
\text { old assisted by the Family } \\
\text { Health Strategy }\end{array}$ & $\begin{array}{l}\text { Pernambuco (house- } \\
\text { hold population sur- } \\
\text { vey) }\end{array}$ & 6-59 & 563 & Not considered & $\begin{array}{l}\text { Probability ratio test } \\
\text { Simple Poisson } \\
\text { regression } \\
\text { Multiple Poisson } \\
\text { regression }\end{array}$ & High \\
\hline $\begin{array}{c}\text { Cobayashi et al.,.23 } \\
2014\end{array}$ & $\begin{array}{l}\text { To examine the preva- } \\
\text { lence of stunting and } \\
\text { overweight in children } \\
\text { and adolescents and iden- } \\
\text { tify associated biochemi- } \\
\text { cal indicators }\end{array}$ & $\begin{array}{c}\text { Acrelândia (AC) } \\
\text { (household survey) }\end{array}$ & $<60$ & 557 & $\begin{array}{l}\text { Reactive protein } C \text { measured by chemilu- } \\
\text { minescence, defining values }>5 \mathrm{mg} / \mathrm{L} \text { as } \\
\text { the indicative of the presence of infec- } \\
\text { tion (analyzes with values adjusted by } \\
\text { the concentration of CRP) }\end{array}$ & $\begin{array}{l}\text { Chi-square } \\
\text { Simple Poisson } \\
\text { regression } \\
\text { Multiple Poisson } \\
\text { regression }\end{array}$ & High \\
\hline $\begin{array}{l}\text { Miglioli et al.,24 } \\
2013\end{array}$ & $\begin{array}{l}\text { To analyze the preva- } \\
\text { lence and factors associat- } \\
\text { ed with VAD in mothers } \\
\text { and their children under } \\
5 \text { years old }\end{array}$ & $\begin{array}{l}\text { Pernambuco (house- } \\
\text { hold survey) }\end{array}$ & 6-59 & 790 & Not considered & $\begin{array}{c}\text { Complementary log- } \\
\text { log model as a link } \\
\text { function }\end{array}$ & High \\
\hline
\end{tabular}


General characteristics and quality evaluation of studies on vitamin A deficiency in Brazilian children less than five years old, according to articles published in the period 2008-2018.

\section{Objective}

Place of study

(months old)

Sample

Investigation of subclinical

Hypothesis testin

Study

Queiroz et al.25

2013

Ferreira et al.,26 To identify the factors 2013

infection

used

To estimate the prevalence of VAD and its associated factors in childre-

Paraíba cities repreenting the regions of the outback, the wild and forest zone (household survey) children

Semi-arid region of Alagoas (household population survey) ship between hemoglobin levels, serum retino concentration and nutritional status in children aged 6 to 59 months old

To determine the prevalence of anemia and VAD and analyze the association of food (in) security with levels of hemogrin and serum retinot in chitdren under 5 years old
Estado da Paraíba (population survey)
6-59

Reactive Protein $C$ measured by Latex Agglutination, defining values $>6 \mathrm{mg} /$ as the indicative of the presence of
infection (analyzes with values adjusted for the concentration of CRP)
foction (analyzes with value adjusted

Reactive Protein C measured by Latex Agglutination, defining the presence of agglutination of visible particles on the test plate as the indicative of the presence of infection (analyzes excluding cases of altered protein)
Poisson regression with robust adjustment of variance

Chi-square Fisher's exact test Poisson regression
High
Not considered

Pearson's Correlation

Coefficient T-student

Multiple Linear

Multiple Linea 
Prevalence of vitamin A deficiency and associated variables in Brazilian children less than five years old, according to articles published in the period 2008-2018.

\begin{tabular}{|c|c|c|}
\hline Author, Year & VAD (\%) & Variables associated with VAD \\
\hline Teles et al.15 2018 & 9.3 & Presence of subclinical infection $(p=0.008)$ \\
\hline Lima et al.,16 2018 & 17.5 & $\begin{array}{l}\text {-Live in the Southeast }(P R=1.59 ; C I 95 \%=1.19-2.17) \text { and in the Northeast } \\
\qquad(P R=1.56 ; C I 95 \%=1.16-2.15) \\
\text {-Live in an urban area }(P R=1.31 ; C l 95 \%=1.02-1.72) \\
\text { - Maternal age } \geq 36 \text { years old }(P R=2.28 ; C I 95 \%=1.37-3.98) \\
\text {-Eat meat every day (protection factor) }(P R=0.61 ; C I 95 \%=1.37-3.98)\end{array}$ \\
\hline Novaes et al.,17 2016 & 13.1 & $\begin{array}{l}\text {-Child's age } \leq 34 \text { months old }(\mathrm{OR}=2.66 ; \mathrm{Cl} 95 \%=1.23-5.74) \\
\text {-Lower maternal age }(\mathrm{OR}=2.39 ; \mathrm{Cl} 95 \%=1.11-5.17)\end{array}$ \\
\hline Silva et al.,18 2015 & 14.0 & $\begin{array}{l}\text {-Low maternal education }(p=0.017) \\
\text {-Low hemoglobin concentration }(p=0.022)\end{array}$ \\
\hline $\begin{array}{l}\text { Figueroa Pedraza et } \\
\text { al.,19 } 2014\end{array}$ & 23.3 & $\begin{array}{l}\text {-No vitamin A supplementation }(p<0.05) \\
\text { - Anemia }(O R=2.21 ; C I 95 \%=1.03-4.84)\end{array}$ \\
\hline Saraiva et al.,20 2014 & 24.7 & $\begin{array}{c}\text { Anemia }(\mathrm{OR}=3,96 ; \mathrm{CI} 95 \%=2.62-6.00) \text { and iron deficiency }(\mathrm{OR}=3.96 ; \\
\qquad \mathrm{CI} 95 \%=2.62-6.00)\end{array}$ \\
\hline Pedraza et al.,21 2014 & 24.4 & No statistical associations were found \\
\hline $\begin{array}{l}\text { Silva de Paula et al.,22 } \\
2014\end{array}$ & 16.0 & $\begin{array}{l}\text {-Inappropriate waste destination }(P R=1.6 ; C I 95 \%=1.1-2.3) \\
\text { - Diarrhea in the last fifteen days }(P R=1.6 ; C \mid 95 \%=1.0-2.4)\end{array}$ \\
\hline Cobayashi et al.,23 2014 & 13.4 & No statistical associations were found \\
\hline Miglioli et al.,24 2013 & 16.1 & $\begin{array}{l}\text {-Lower maternal age }(P R=3.00 ; C I 95 \%=1.43-6.31) \\
\text {-Fewer number of prenatal consultations }(P R=3.99 ; C I 95 \%=1.41-11.30) \\
\text {-Low birth weight }(P R=2.80 ; C I 95 \%=1.22-6.42) \\
\text { - Maternal VAD }(P R=3.99 ; C I 95 \%=1.73-9.19) \\
\text {-Diarrhea in the last } 15 \text { days }(P R=1.88 ; C I 95 \%=1.04-3.41)\end{array}$ \\
\hline Queiroz al.,25 2013 & 21.8 & $\begin{array}{l}\text {-Presence of subclinical infection (OR }=2.55 ; \mathrm{Cl} 95 \%=1.74-3.75) \\
\text {-Presence of water at home (protection factor) }(\mathrm{OR}=0.65 ; \mathrm{Cl} 95 \%=0.45-0.96)\end{array}$ \\
\hline Ferreira et al.,26 2013 & 45.4 & $\begin{array}{l}\text {-Age of the child from } 12.1 \text { to } 24 \text { months old }(P R=1.45 ; C I 95 \%=1.04-2.02) \\
\text {-Low birth weight }(P R=1.41 ; C I 95 \%=1.07-1.86) \\
\text {-Low maternal education }(P R=1.66 ; C \mid 95 \%=1.12-2.44)\end{array}$ \\
\hline Gondim et al.,27 2012 & 21.4 & Anemia $(P R=1.38 ; C l 95 \%=1.10-1.74)$ \\
\hline Oliveira et al.,28 2010 & 20.6 & $\begin{array}{l}\text {-Male }(p=0.03) \\
\text {-Lower per capita income }(p<0.01) \\
\text {-Absence of cell phone }(p=0.04) \\
\text { - Absence of sanitary sewage }(p=0.05)\end{array}$ \\
\hline
\end{tabular}

VAD $=$ vitamin A deficiency . 
Figure 2

Forest Plot of the prevalence of vitamin A deficiency in Brazilian children less than five years old, according to articles published between 2008-2018.

Study

Basic Health Unit 18,20

Silva et al., 182015

Saraiva et al.,20 2014

Subtotal

Daycare Center $17,19,21$

Novaes et al., 172016

Figueroa Pedraza et al.,19 2014

Pedraza et al.,21 2014

Subtotal

Household Survey15,16,22-28

Teles et al.,15 2018

Lima et al.,16 2018

Silva de Paula et al.,22 2014

Cobayashi et al.,23 2014

Miglioli et al.,24 2013

Queiroz al.,25 2013

Ferreira et al.,26 2013

Gondim et al.,27 2012

Oliveira et al. 282010

Subtotal $\left(I^{2}=96.14 \% ; p=0.00\right)$

Heterogeneity between groups: $p=0.912$

Total $(\mid 2=94.53 \% ; p=0.00)$
Prevalence (Cl95\%)

$\%$ Weight
$0.14(0.10-0.19)$

$0.25(0.22-0.28) \quad 7.30$

$0.21(0.18-0.24)$

$0.13(0.10-0.18) \quad 7.00$

$0.23(0.18-0.29) \quad 6.52$

$0.24(0.19-0.31) \quad 6.22$

$0.20(0.12-0.28)$

$0.09(0.05-0.16) \quad 6.56$

$0.18(0.16-0.19) \quad 7.75$

$0.16(0.13-0.19) \quad 7.36$

$0.13(0.11-0.17) \quad 7.41$

$0.16(0.14-0.19) \quad 7.49$

$0.22(0.20-0.24)$

$0.45(0.41-0.50) \quad 6.98$

$0.21(0.19-0.24)$

$0.21(0.18-0.23)$

$0.20(0.16-0.24) \quad 66.11$

$0.20(0.17-0.23)$

The values of the articles were obtained through random effects.

\section{Table 3}

Synthesis of the variables associated with vitamin A deficiency in Brazilian children less than five years old, according to articles published between 2008-2018.

Studies according to sample origin Variables associated with vitamin A deficiency in more than one article

Basic Health Unit 18,20

Daycare center $17,19,2$

Household survey15,16,22-28

Total15-28
Deficient nutritional status of iron

Low weight at birth

Presence of subclinical infection

Inadequate basic sanitation conditions

Child's lower age

Low weight at birth

Deficient nutritional status of iron

Diarrhea in the last fifteen days

Presence of subclinical infection

Inadequate basic sanitation conditions

Lower maternal age

Lower maternal education 
nutrition education actions, suggesting the need for training of health professionals. ${ }^{30,31}$ Also, such programs face great challenges in their coverage and sustainability, and for not being able to address the underlying problem of inadequate vitamin A food intake and chronic deficiency in isolation. ${ }^{10}$ In this sense, according to a literature review, ${ }^{32}$ supplementations with a megadose of vitamin A should be analyzed since the effects of the intervention may still be compromised as a consequence of the change in disease patterns (notably, reductions in measles and diarrhea). Thus, the authors reinforce the importance of daily vitamin A intake and food fortification and regular supplementation with low doses. ${ }^{32}$ As an example, there are the results achieved in Central American countries, in which there was a significant reduction of VAD in children under 6 years old, probably due to the adoption of multiple strategies to control this deficiency, mainly the universal sugar fortification. 29

According to the arguments of other researchers, the persistence of high prevalence of deficiency may be related to the inaccessibility to foods rich in vitamin A, insufficient dietary diversity, fractional food fortification, frequent exposure to infectious processes, and the restricted effect of supplementation for short periods. 9,33 In the previous context of the factors associated with VAD, this study mainly allowed to verify the influence of exposures related to the development of infectious processes, which is similar to the result of a specific review focusing on children assisted in daycare centers. ${ }^{8}$ Frequent infections, especially diarrhea and respiratory problems, can affect serum retinol levels due to low food intake, malabsorption, and increased vitamin A catabolism. Furthermore, VAD once installed can reduce immune resistance to these diseases, generating a vicious cycle of nutritional deficiency and infections in children. 8,18

The effects of infectious processes on retinol concentrations can be observed in the first 24 hours after the onset of infection, even in the so-called subclinical phase. 25 This phenomenon is particularly important in the child population given its susceptibility to infectious diseases, 17,34 which can explain the associations found.

The deficiency of vitamin A and iron finds reasons linked to the presence of common etiological factors that comprise characteristics of the context of social vulnerability related to food security, environmental health, health services, and care practices. 19 The reduction in serum levels retinol may be also a consequence of the metabolic interactions between vitamin A and iron. Iron deficiency can affect the use of vitamin A by the human body and feedback loops are generated between the two deficiencies. 19,34 In a review study focusing on Sri Lanka, with similar results, instead of isolated emphases, the authors emphasized the importance of worry about the simultaneous deficiency of several micronutrients and their interactions during the screening and treatment of these problems. 35

In the context of a previous causality with a focus on the influence of infectious processes on the nutritional status of vitamin $\mathrm{A}$, inadequate environmental sanitation and hygiene conditions stand out for having direct impacts on the development of infectious diseases, particularly diarrhea, which explains the associations found of VAD with inappropriate waste disposal and water supply.36 Similar national studies results have been reported not only among Brazilian children. 37

For the other factors that have been systematized with importance in VAD, the influence of maternal and child characteristics is highlighted. Differences in prevalence may be associated with the age of the children, as seen in the semi-arid region of Alagoas that infants were more vulnerable than preschoolers. 26 The decrease in the prevalence of VAD with the child's age suggests that it is because of the greater susceptibility of younger children to diseases such as intestinal and respiratory infections that can cause anorexia, malabsorption and greater catabolism, impairing the nutritional status of the nutrient. 17,26 Children born with low birth weight may have deficient levels of vitamin As a consequence of the nutrient's deficient nutritional status also in the mother, which influences the child's cell stocks, reinforcing the need for preventive measures even in the gestational period. 26 Worse maternal nutrition, lower socioeconomic level and the lower capacity for care at this age may be an explanation of the VAD in children of younger mothers, a fact that can interfere with the food offered to the child. 17,24 The association of maternal education with hypovitaminosis A occurs similarly to age, highlighting the relevance of education in preventive care, in the management of diseases and in the understanding of guidelines provided by health professionals. Greater instruction enables the mothers to achieve better socioeconomic status and sanitary housing conditions. 18

When interpreting the results, we can consider some limitations. First, the inclusion of articles identified in only three bibliographic bases, which was minimized by consulting the lists of bibliographic references of the articles previously included in the review. Also, the limited number of articles on VAD 
that have been systematized.Yet, it is important to highlight the evaluation of the quality of the articles showed restrictions in the selection of the sample in some of them, admitting the possibility of bias in this sense. Despite this, the relevance of the results obtained should be highlighted considering the difficulty of studies related to the diagnosis of the nutritional status of vitamin A, especially at the national and multicentric level.

\section{Conclusions}

VAD is still poorly studied in Brazilian children under the age of five. The average prevalence weighted by the sample size identified in this review suggests a serious public health problem, highlighting the susceptibility of children conditioned to the nutritional status of deficient iron, the presence of diarrhea, the diagnosis of subclinical infection, the low birth weight and younger ageas risk factors. Furthermore, younger age and lowermaternal education, as well as inadequate environmental sanitation conditions also seem to be important predictors of deficiency. Further studies are needed on VAD in Brazilian children under the age of five.

\section{Author's contribution}

Figueroa Pedraza D participated in the design of the article, bibliographic review, analysis, and interpretation of data, writing, and approval of the article.

\section{References}

1. WHO (World Health Organization). Global prevalence of vitamin A deficiency in populations at risk 1995-2005: WHO global database on vitamin A deficiency. Geneva; 2009.

2. Tariku A, Fekadu A, Ferede AT, Abebe SM, Adane AA. Vitamin-A deficiency and its determinants among preschool children: a community based cross-sectional study in Ethiopia. BMC Res Notes. 2016; 9: 323.

3. Song P, Wang J, Wei W, Chang X, Wang M, An L. The Prevalence of Vitamin A Deficiency in Chinese Children: A Systematic Review and Bayesian Meta-Analysis. Nutrients.2017; 9:1285.

4. Wirth JP, Petry N, Tanumihardjo SA, Rogers LM, McLean E, Greig A, Garrett GS, Klemm RDW, Rohner F. Vitamin A Supplementation Programs and Country-Level Evidence of Vitamin A Deficiency. Nutrients. 2017; 9: 190

5. Bailey RL, West Jr KP, Black RE. The epidemiology of global micronutrient deficiencies. Ann Nutr Metab. 2015; 66 (Suppl. 2): 22-33.

6. Galicia L, Grajeda R, López de Romaña D. Nutrition situation in Latin America and the Caribbean: current scenario, past trends, and data gaps. Rev Panam Salud Publica. 2016; 40 (2): 104-13.

7. Brasil. Ministério da Saúde. Pesquisa Nacional de Demografia e Saúde da Criança e da Mulher - PNDS 2006: Dimensões do processo reprodutivo e da saúde da criança. Brasília, DF; 2006. (Série G. Estatística e Informação em Saúde).

8. Figueroa Pedraza D, Rocha ACD. Deficiências de micronutrientes em crianças brasileiras assistidas em creches: revisão da literatura. Ciênc Saúde Colet. 2016; 21 (5): 1525-43.

9. Stevens GA, Bennett JE, Hennocq Q, Lu Y, De-Regil LM, Rogers L, Danaei G, Li Gwhite RA, Flaxman SR, Oehrle SP, Finucane MM, Guerrero R, Bhutta ZA, Then-Paulino
A, Fawzi W, Black RE, Ezzati M. Trends and mortality effects of vitamin A deficiency in children in 138 lowincome and middle-income countries between 1991 and 2013: a pooled analysis of population-based surveys. Lancet Glob Health. 2015; 3: e528-e536.

10. Miranda WD, Guimarães EAA, Campos DS, Antero LS, Beltão NRM, Luz ZMP. Programa Nacional de Suplementação de Vitamina A no Brasil: um estudo de avaliabilidade. Rev Panam Salud Publica. 2018; 42:e182.

11. Brasil. Ministério da Saúde. Manual de condutas gerais do Programa Nacional de Suplementação de Vitamina A. Brasília, DF; 2013.

12. Ramalho A, Padilha P, Saunders C. Análise crítica de estudos brasileiros sobre deficiência de vitamina A no grupo materno-infantil. Rev Paul Pediatr. 2008; 26 (4): 3929.

13. Rubin LP, Ross AC, Stephensen CB, Bohn T, Tanumihardjo SA. Metabolic effects of inflammation on vitamin A and carotenoids in humans and animal models. AdvNutr.2017; 8(2):197-212.

14. Munn Z, Moola S, Riitano D, Lisy K. The development of a critical appraisal tool for use in systematic reviews addressing questions of prevalence. Int J Health Policy Manag. 2014; 3: 123-8.

15. Teles LFS, Paiva AA, Luzia LA, Lima-Ferreira FEL, Carvalho CMRG, Rondó PHC. The relationship between serum retinol concentrations and subclinical infection in rural Brazilian children. Rev Nutr. 2018; 31 (3): 299-310.

16. Lima DB, Damiani LP, Fujimori E. Deficiência de vitamina A em crianças brasileiras e variáveis associadas. Rev Paul Pediatr. 2018; 36 (2): 176-85.

17. Novaes TG, Gomes AT, Silveira KC, Souza CL, Lamounier JA, Netto MP, Capanema FD, Rocha DS. Prevalência e fatores associados com deficiência de vitamina A em crianças atendidas em creches públicas do Sudoeste da 
Bahia. Rev Bras Saúde Mater Infant. 2016;16 (3): 337-44.

18. Silva LLS, Peixoto MRG, Hadler MCCM, Silva SA, Cobayashi F, Cardoso MA. Estado nutricional de vitamina A e fatores associados em lactentes atendidos em Unidades Básicas de Saúde de Goiânia, Goiás, Brasil. Rev Bras Epidemiol. 2015; 18 (2): 490-502.

19. Pedraza DF, Sales MC. Prevalências isoladas e combinadas de anemia, deficiência de vitamina A e deficiência de zinco em pré-escolares de 12 a 72 meses do Núcleo de Creches do Governo da Paraíba. Rev Nutr. 2014; 27(3):301-10.

20. Saraiva BCA, Soares MCC, Santos LC, Pereira SCL, Horta PM. Deficiência de ferro e anemia estão associadas com baixos níveis de retinol em crianças de 1 a 5 anos. J Pediatr. 2014; 90(6):593-9.

21. Pedraza DF, Queiroz D, Paiva AA, Cunha MAL, Lima ZM Seguridad alimentaria, crecimiento y niveles de vitamina A hemoglobina y zinc en niños preescolares del nordeste de Brasil. Ciênc Saúde Coletiva. 2014; 19 (2): 641-50.

22. Silva de Paula WKA, Caminha MFC, Figueirôa JN, Batista Filho M. Anemia e deficiência de vitamina A em crianças menores de cinco anos assistidas pela Estratégia Saúde da Família no Estado de Pernambuco, Brasil. Ciênc Saúde Coletiva. 2014; 19 (4): 1209-22.

23. Cobayashi F, Augusto RA, Lourenço BH, Muniz PT, Cardoso MA. Factors associated with stunting and overweight in Amazonian children: a population-based, crosssectional study. Public Health Nutr. 2014; 17 (3): 551-60.

24. Miglioli TC, Fonseca VM, Gomes Junior SC, Lira PIC, Batista Filho M. Deficiência de Vitamina A em mães e filhos no Estado de Pernambuco. Ciênc Saúde Coletiva. 2013; 18 (5): 1427-40

25. Queiroz D, Paiva AA, Pedraza DF, Cunha MAL, Esteves GH, Luna JG, Diniz AS. Deficiência de vitamina A e fatores associados em crianças de áreas urbanas. Rev Saúde Pública. 2013; 47 (2): 248-56.

26. Ferreira HS, Moura RMM, Assunção ML, Horta BL. Fatores associados à hipovitaminose $\mathrm{A}$ emcrianças menores de cinco anos. Rev Bras Saúde Matern Infant. 2013; 13 (3): 223-35.

27. Gondim SSR, Diniz AS, Cagliari MPP, Araújo ES, Queiroz D, Paiva AA. Relação entre níveis de hemoglobina,concentração de retinol sérico e estadonutricional em crianças de 6 a 59 meses doEstado da Paraíba. Rev Nutr. 2012; 25 (4): 441-9.
28. Oliveira JS, Lira PIC, Osório MM, Sequeira LAS, Costa EC, Gonçalves FCLSP, et al. Anemia, hipovitaminose A e insegurança alimentar em crianças de municípios de Baixo Índice de Desenvolvimento Humano do Nordeste do Brasil. Rev Bras Epidemiol. 2010; 13 (4): 651-64.

29. Cediel G, Olivares M, Brito A, Romaña DL, Cori H, La Frano MR. Interpretation of Serum Retinol Data From Latin America and the Caribbean. Food Nutr Bull. 2015; 36 (Suppl. 2): S98-108.

30. Brito VRS, Vasconcelos MGL, Diniz AS, França ISX, Pedraza DF, Peixoto JBS, Paiva AA. Percepção de profissionais de saúde sobre o programa de combate à deficiência de vitamina A. Rev Bras Promoç Saúde. 2016; 29 (1): 93-9.

31. Rodrigues LPF, Roncada MJ. A educação nutricional nos programas oficiais de pre-venção da deficiência da vitamina A no Brasil. Rev Nutr. 2010; 23(2):297-305.

32. Mason J, Greiner T, Shrimpton R, Sanders D, Yukich J. Vitamin A policies need rethinking. Int J Epidemiol.2015; 44 (1): 283-92.

33. Palmer AC, West KP Jr, Dalmiya N, Schultink W. The use and interpretation of serum retinol distributions in evaluating the public health impact of vitamin A programmes. Public Health Nutr. 2012; 15: 1201-15.

34. Sales MC, Pedraza DF. Parâmetros Bioquímicos do Estado Nutricional de Micronutrientes e seu significado para as ações de saúde pública. Espaço Saúde. 2013; 14 (1 e 2): 94103.

35. Abeywickrama HM, Koyama Y, Uchiyama M, Shimizu U, Iwasa Y, Yamada E, Ohashi K, Mitobe Y. Micronutrient Status in Sri Lanka: areview. Nutrients. 2018; 10 (11): 1583.

36. Figueroa Pedraza D. Hospitalização por doenças infecciosas, parasitismo e evolução nutricional de crianças atendidas em creches públicas Ciênc Saúde Coletiva. 2017; 22 (12): 4105-14.

37. Jayatissa R, Gunathilaka MM. Vitamin A Nutrition Status in Sri Lanka 2006. Department of Nutrition, Medical Research Institute, Ministry of Healthcare and Nutrition in collaboration with UNICEF: Colombo, Sri Lanka; 2006 Disponível em: https://www.researchgate.net/publication/281119879_VITAMIN_A_NUTRITION_STATUS_IN _SRI_LANKA_2006

Received on March 12, 2019

Final version presented on February 13, 2020

Approved on June 19, 2020 